\title{
THE PERSONALITY OF A TEACHER IN THE GOOD DOING OF ACADEMICIAN IVAN ZYAZYUN (TO THE 80 ${ }^{\mathrm{TH}}$ BIRTHDAY ANNIVERSARY)
}

\author{
HRYHORIY VASIANOVYCH
}

\begin{abstract}
The article analyzes the works by academician Ivan Zyazyun in the framework of the teacher's good doing. It is proved that the prominent scientist of Ukraine considered this problem on the humanistic principles of human creation and the existential nature of human existence. I. Zyazyun states that human is the only living being that does not belong to its lineage group from the moment of birth. Its human essence is acquired throughout whole life. I. Zyazyun as the philosopher and the teacher substantiated the opinion, according to which the worldview of a personality becomes determinant in the process of good going. The humanistic worldview of the personality of a teacher allows creating of his/her own activity aimed at mental, spiritual and intellectual development of students, and to treat them as active and equal subjects of the educational process. Good doing of a teacher forms the spiritual elite of the nation. The spiritual elite is distinguished by the fact that it forms the ideals of good, unites the best forces of the nation to make new cultural achievements. The scholar paid considerable attention to the issues of forming common and collective good doing. It allows all the members of the team to act responsibly, actively and productively for the approval of not only individual but also the common good and welfare.
\end{abstract}

Keywords: human, personality, teacher, good doing, humanity, worldview, conscious, pedagogical activity, relations.

\section{INTRODUCTION}

Modern humanitarian science actively investigates the question of the essence and existence of a human, the possibility of its real changes and the acquisition of new characteristics. Instead, the approaches to this complex problem remain to be different, even opposite. However, its image and model are mostly considered on the basis of reflection. There is a fairly noticeable gathering into a single whole of humanistic worldview, therefore life-purpose questions of human existence come to the forefront. Academician I. Zyazyun states that human is the only living being that does not belong to its lineage group from the moment of birth. Its human essence is acquired throughout whole life. This acquisition can raise a person to the highest altitudes, but sometimes the process of its development can be too slow, and in that case a person becomes unrealized in society, its aspirations and needs can remain on a primitive level. In this situation, a person cannot become a real personality. As the scholar 
proves, Personality and Human are distinguished by the fact that the first is an instrument or means of organizing the second. The first one gets meaning and vitality in the second one [3, p. 326].

Therefore, the question of studying the quality of human life, the real possibilities for the development and self-development of an individual, its freedom, the sense of existence, etc. becomes of a great importance. Teacher as a Human should be realized on a high level of a Personality, since, as nobody else, he/she is called to create a holistic spiritual person, which means that teacher has to treat oneself and others with a high degree of responsibility, humanity, and kindness. Academician I. Zyazyun emphasized on this aspect of the problem, since he was paragon of goodness, and consistently proved that the future of the nation, its culture, welfare, and worthy affirmation in the modern globalized world depends on the activity of a teacher.

The objective of the article is to analyze the scientific works by I. Zyazyun in the aspect of a teacher's good doing.

The subject matter of the article. Studying the enormous scientific heritage of academician I. Zyazyun is still to be researched. However, even today a significant number of scientists devoted their works to certain aspects of the scientific work of the outstanding Ukrainian scholar, cultural and educational figure of the XX-XXI centuries (V. Bykov, O.Budnyk, R. Gurevych, O. Dubaseniuk, V. Kremen, A. Kuzminsky, L. Lukianov, N. Nychkalo, O. Otych, E. Pomytkin, L. Pukhovska, B. Rybalka, L. Khomych and others).

Through his multifaceted and conscientious work, I. Zyazyun proved that the main thing in pedagogical activity should be the creation of goodness, and sincere love for a human. The scholar implemented this thought into practice throughout his life. He himself repeatedly emphasized that he discovered it due to the "philosophy of the heart" by H. Skovoroda, P. Yurkevych, and also by studying works of F. Disterveg, M. Korf, T. Lubentsa, A. Makarenko, I. Ohienko, S. Rusova, V. Sukhomlynsky and under the influence of his teacher Vyacheslav Kudin. Therefore, it becomes quite clear that the epitome of scientist's life became such well-known works as "Pedagogy of good" [4], "Beauty of pedagogical action" [2], "Pedagogical mastery" [5].

\section{ANALYSIS AND DiscUSSION}

I. Zyazyun considered the profession of a teacher to be one of the most needed and most demanded on earth, therefore, he proved that the status of a Teacher should be top-priority, the highest in society. Thus, if society wants to make children happy, then it must create all the conditions for a happy teacher's life. The scholar, the first Minister of Education and Science of Independent Ukraine, wrote: "... by this time, I am convicted that a teacher is the fundamental force of social reproduction - cultural, economic, and political. Social progress, any achievements of the state and the people are impossible without teacher. Pedagogue is a direct productive force. History confirms that fact as well as modern life does. Without a teacher, an impending future is impossible. Probably, this is a planetary regularity" [4, p.13].

In this sense it is quite logical, that it was the academician I. Zyazyun who became the author of the concept "Teacher" that acquired the national status. Unfortunately, due to the reasons of socio-political and economic instability, it has not been fully realized. This cost the scientist profound emotional distress...

I. Zyazyun considered pedagogical activity as a complex organized system, which included direct teaching (functional level), reflexive activity (supporting the former one), methodical (it is aimed at the selection and construction of teaching aids of educational subjects), and finally it is the activity that integrates educational subjects in the one unit - the activity of programming. At the same time, the scientist stressed that "the current socio-cultural situation and education problems require that teachers-methodologists are engaged into the description and projection of the study goals. Firstly, it is necessary, because modern production-practical activity sets only clearly defined goals and tasks that can be solved only by specially trained people. Secondly, modern methodological thinking can effectively design learning processes, but it requires clear and defined goals from the customer. Thirdly, 
modern technological society is developed rapidly and intensively and requires the same from systems of teaching ..." [7, p. 230].

According to the scientist, teacher must continually improve himself, grow spiritually, but the pedagogical skill is not an end in itself, it must be directed at the good of the disciple. In this sense, it is important for a teacher to show good doing at three levels: consciousness, activity, and relationships.

The level of consciousness reflects the attitudes of a teacher, primarily his orientation to humanistic values, intellectual and emotional development of the student's personality. Thus, this is what is called "the mind of culture" (V. Bibler). Self-reflection upon one's good doing has a great cultural force and significance in teacher's everyday life when he/she realizes a great inner joy: to do good not because it is a professional duty, but because it is otherwise impossible to be happy, without this creation the meaning of existence is lost. The conscious doing good is that living and light ray that connects a teacher and a disciple. This is the exact moment when a person finds one's "better" side. One is no longer capable of living only with a negation of evil, but consistently and steadily asserts mutual understanding, when another's grief becomes yours. The heart and the mind of goodness are echoing an optimistic "yes!": You are not alone in this world, and I (the teacher) am coming to help you! This spiritual kindness is full of the feeling of human unity, regardless of social status, age characteristics, etc. Thus, as I. Zyazyun has repeatedly emphasized, the culture of a teacher is impossible without the conscious good doing. Instead, the scholar gave considerable attention to the expression of the kindness at the subconscious level of a teacher. Especially interesting in this sense are the following works: "The role of the subconscious in the development of a personality" [8], "Unconscious and creative intuition" [1].

Analyzing various psychological theories regarding the understanding of the essence and content of the subconscious, its relationship with the conscious, I. Zyazyun makes it clear that he follows the idea of unity between the subconscious and the mindset substantiated by the famous Georgian psychologist D. Uznadze. According to his proofs, both conscious and subconscious are involved in the process of good doing based on the mindset of a personality. "Mindset is a preliminary preconscious reflection of the object in the state of the subject as an integral whole, made on the basis of the interrelationship of the living being - the carrier of all mental and biological capabilities, all the already established experience, and those objective conditions in which it realizes its needs. The mindset is an integral subjective state in which the whole subject in general, all his mental and physical strength and capabilities are focused and mobilized in accordance with those objective conditions, determine the emergence and formation of this state" [8, p. 195]. In addition, according to the scholar, motives and needs play a significant role in good doing. The principle of "social energy" also impresses the scientist. It was formulated by the German professor G. Ammon, according to which, to transmit positive energy is nothing else but to understand another person, to show interest in it, and to give everything what is possible and necessary for that person at the moment. The principle of benevolent attitude towards a person has a positive influence on the behavior of the individual, and makes him better, kinder, contributes to the development of his emotional and volitional sphere. In addition, it is worth remembering that the subconscious mind always served the function of protecting consciousness.

Analyzing good doing at the level of activity I. Zyazyun stressed that "...the strategic line of teacher's activity that is the formation of the personality of a student ... should be regarded as a kind of meta-activity, which is built upon the activity of a student" [5, p. 18-19].

According to the scholar, the activity of a teacher involves not only the reproduction of the inner world of a student, but also suspects the active and purposeful transformation of this world in accordance with the goal of education and training. "Taking into consideration that these transformations are possible under the conditions of the activity of a student himself, we can conclude that the task of a teacher is to create conditions that would ensure this activity (the formation of motivation, the development of cognitive interests, teaching the methods of educational work). Such management of another person's activity is called reflexive" [5, p. 20].

Consequently, pedagogical activity in its character and according to its purpose is creative; it is directed at the creation of good. However, this is only a subjective aspect of the creativity of a teacher, 
his inner willingness to do well. But one should not forget its objective factors, the first of which is the creation of proper conditions and real possibilities to ensure the creation process. I. Zyazyun constantly emphasized that to do good, in the broadest sense of the word means that the teacher will do his best when he does not feel humiliated, materially and spiritually distorted. Socially protected teacher is in a state of "mental equilibrium" (H. Skovoroda), and this equilibrium, good mood, spiritual experience, optimism, he passes on to the pupils. According to I. Zyazyun, the main thrust of the teacher's good doing is to teach students/pupils of the selfless good doing for others, not to lock themselves in the shell of egoism, indifference, and so on. This is exactly what constitutes objective and subjective essence of a human existence.

The scholar considered good doing to be great unifying force at the level of activity. After all, people are interconnected more than just by interaction; they are united by interaction in goodness. Good doing is the creation of certain spiritual hygiene, which makes it impossible to be infected by the bacilli of human evil, aggression, and despiritualization. Moreover, I. Zyazyun stressed that good doing of a teacher forms the spiritual elite of the nation. In his paper "Problems and Prospects for the Formation of a National Humanitarian and Technical Elite", he wrote: "Spiritual elite differ from political, economic or professional by the primacy of moral humanistic principles. Spiritual elite is determined primarily by searching new moral ideals and ways of recreation a great society; by finding new more perfect, decent means of unifying people, by aspiring to higher goals" [6, p. 33]. Substantiating the idea of good going at the level of relations, I. Zyazyun stressed that its most complicated form is mutual good doing. A great supporter of A. Makarenko's ideas, I. Zyazyun devoted his main pedagogical work "Pedagogical mastery", to this outstanding teacher-experimenter, whose activity was aimed at creating true collectivistic relations, where mutual respect, honor and dignity of each member of the team, humane attitude of a teacher to a student, and vice versa would dominate. Mutual good doing begins with communication. In this regard, the scholar wrote: “... pedagogical communication as a professional-ethical phenomenon requires from a teacher special training not only for mastering the technology of interaction, but also for gaining moral experience, pedagogical wisdom in the organization the relations with students, parents, colleagues in various fields of educational process. Pedagogical communication can be professional and not professional depending on qualitative features. Professional pedagogical communication at the level of interaction provides students with the translation of a human culture, assists in the acquisition of knowledge, promotes the formation of value orientations in the process of opinions exchange; ensures the formation of a child's dignity" [5, p. 200].

The pedagogical team, run by a true professional, creates an atmosphere of trust, mutual respect, mutual help, in which one wants to think and act independently, to do good deeds. I. Zyazyun indicates that real pedagogical communication is not only multifaceted but also multifunctional. Orientation in the field of communication functionality enables a teacher to organize interaction in the classroom and beyond, it creates conditions for the exchange of attitudes, experiences, helps each student to assert himself in the team, ensuring cooperation and co-creation for good deeds.

I. Zyazyun always regarded pedagogical communication as a dialogue, which recognizes the equality, openness of partners in this process, free expression of their own thoughts. The humane style of dialogue provides an enthusiasm for joint creativity, which main meaning is good doing.

We should also mention the following: outstanding scholar and teacher-practitioner I. Zyazyun emphasized that the mutual creation of good is an effective obstacle to the various manifestations of evil. He never idealized reality and perceived it as it was. However, he sincerely worried when he could not overcome evil as an abnormality of human existence. In an afterword to the book "Pedagogy of good", I. Zyazyun wrote about people who do not know how to do good the following: "it is not fault of those people who cannot make good or do not want to do it, it is their great misery and personal tragedy. They are not trained, not brought up, not enriched with the great purpose of Good and Love, Truth and Beauty" [4, p. 307]. 


\section{CONCLUSIONS}

In view of the above-mentioned we can draw the following conclusions:

1. The philosophical and pedagogical discourses of academician Ivan Zyazyun are aimed at human creation, the main of which is good creativity, spiritual growth of a personality.

2. I. Zyazyun considered the idea of good doing on three mutually interconnected and interdependent levels: ideological, activity level, and level of human relations.

\section{REFERENCES}

[1] Zyazyun I. Unconscious and creative intuition. Professional education: pedagogy and psychology, 4 (2003), 121-135. (in Ukrainian)

[2] Zyazyun I. Beauty of pedagogical action. Manual for teachers, graduate students, and students of higher educational institutions. URIMB, Kyiv, 1997. (in Ukrainian)

[3] Zyazyun I. A human in the context of humanitarian philosophy. Professional education: pedagogy and psychology, 1 (1999), 323-333. (in Ukrainian)

[4] Zyazyun I. Pedagogy of goodness: ideals and realities. Scientific and methodical manual. MAUP, Kyiv, 2000. (in Ukrainian)

[5] Zyazyun I. Pedagogical mastery. Higher school, Kyiv, 1997. (in Ukrainian)

[6] Zyazyun I. Problems and prospects of the formation of the national humanitarian and technical elite. In: Tovazhnyansky L., Romanovsky O. (Eds). NTU “HPI”, Kharkiv, 2003. (in Ukrainian)

[7] Zyazyun I. Teacher's profession from the point of view of pedagogical mastery. In: Pedagogical and psychological science in Ukraine. Professional education and adult education, 4. Pedagogical thought, Kyiv, 2012. (in Ukrainian)

[8] Zyazyun I. The role of the subconscious in the development of personality. In: Professional education: pedagogy and psychology, 2 (2000), 183-215. (in Ukrainian)

[9] Zyazyun I. Philosophy of pedagogical worldview. In: Professional education: pedagogy and psychology, 6 (2004), 209-222. (in Ukrainian)

Address: Hryhoriy Vasianovych, Lviv State University of Life Safety, 35, Kleparivska St., Lviv, 79000, Ukraine.

E-mail: wasianowych@ukr.net.

Received: 10.11.2017; revised: 15.03.2018.

Васянович Григорій. Особистість учителя у добротворчій дії академіка Івана Зязюна (до 80-ліття від дня народження вченого). Журнал Прикарпатського університету імені Василя Стефаника, 5 (1) (2018), $17-22$.

У статті аналізуються наукові праці академіка Івана Зязюна в контексті добротворчої діі вчителя. Доведено, що видатний учений України розглядав цю проблему на гуманістичних принципах існування людини та екзистенціальному характері людського буття. І. Зязюн стверджує, що людина є єдиною живою істотою, яке не належить до своєї родини з моменту народження. Ї̈і людська сутність формується протягом усього життя. І. Зязюн як філософ та вчитель обгрунтував 
думку, згідно з якою світогляд особистості стає визначальним у процесі добротворчості. Гуманістичний світогляд особистості вчителя дозволяе створювати свою власну діяльність, спрямовану на психічний, духовний та інтелектуальний розвиток учнів, а також розгдядати їх як активних та рівноправних суб'єктів навчального процесу. Добра діяльність педагога формує духовну еліту нації. Духовна еліта вирізняється тим, що вона формує ідеали добра, об'єднуе кращі сили нації, щоб досягти нових культурних досягнень. Учений приділяв значну увагу питанням формування спільного та колективного добробуту. Це дозволяє всім членам команди діяти відповідально, активно та продуктивно заради творення не дише особистості, а й загального блага та добробуту.

Кдючові слова: людина, особистість, учитель, добротворчість, людство, світогдяд, педагогічна діяльність, взаємини. 